\title{
THE STUDY OF LAW IN THE THEORY OF LEADERSHIP JOHN E. MAXWELL AS WELL AS ITS APPLICATION AGAINST THE LEADERSHIP OF THE EFFECTIVE
}

\author{
Ranto \\ Efrata Evangelical Theology College - Sidoarjo \\ E-mail: rantoasmaredja@gmail.com
}

\begin{abstract}
In the Legal Foundation That Vamp this, the cornerstone of which is the basis for true leadership it is the belief, not the belief in the sense of faith or religion, but rather a statement of the credibility of someone that can be trusted, or childbirth trust of those they lead. So trust is the cornerstone of leadership. The Law Of True Leadership: Apply The Law Of-This Law Then People Will Become Your Followers. While the confidence in his own awakened/formed mainly from the role of the character and integrity to be a key factor for the creation of trust in leadership. That character is the basis of the defense is at the root of the realization of beliefs that sustain and maintain its leadership of the collapse. While trust is the cornerstone of strong leadership.
\end{abstract}

Keywords: leadership, Law, Effective, Integrity, Character

\section{INTRODUCTION}

As leadership in general, more so in Christian leadership, thinking and discussion about true leadership can not be separated with a qualification of a leader that mesh closely in the quality of its leadership. Similarly, when talking about the law foundation is steady in true leadership. As confirmed by Maxwell, the law foundation of steady leadership is more related to the character and personality of the leader, which then sustains the leadership of the executable.[1] Even more, so it can be attributed to strong leadership, impact, and influence of the grate thereof, as well as being the motivation and stimulation for the people who follow the leadership and vision.[2] Here begins the apparent close relationship between the two, in this case, the contribution of the implementation of the law foundation of such strong support true leadership.

The Foundation of a steady, which is the basic that sustains the leadership it is the belief, [3] while his own beliefs are formed and built from the character and credibility of the private lenders who are full of integrity.[4] 
The integrity of the character and credibility of the private good is characterized by the unity between all the qualifications of the character and credibility of the person with the realization sincere in life. That's the law of the Runway Steady for true leadership. As is evident in the practice, that this principle is a theorem undeniable for strong leadership and survival.

Failure to realize the law foundation of steady makes a person's leadership collapse - no matter how the breadth of connection and talented the person is, it causes very severe damage, it is often difficult to be excused or tolerated by other people/followers. If these conditions can then be repaired, it will require a very long time, and the consequences are a very great price. Trust is the cornerstone of which became the basis of which support the building of leadership in it.[5] It becomes clear here that the foundation of trust in leadership is the factor most crucial that allows the leadership of its running, and even firm.

His position as a foundation to support the building of leadership is irreplaceable by other factors. It is fitting if this was said as the law of the runway because, in addition to being the basis that sustains leadership, this law asserts that from this point that the strong leadership began. However, unfortunately, integrity is the key factor that builds trust - and provides a foundation of a steady - this, in the observation of the Maxwell became a commodity that is disappearing in leadership in today's world.[6] A fundamental error and start a common occurrence, it is as though the foundation of it can be replaced with competence, academic qualifications, experience, and so on. While the actual, foundation for integrity - trust is irreplaceable. Maxwell says, that "of all the laws of leadership, the Law Foundation of Steady is the most important", and may not be replaced by another.[7]

Stephen R. Covey calls this foundation an "ethics of character", which is a statement of personal qualification which includes: integrity, humility, fidelity, self-control, courage, justice, patience, industry, simplicity, modesty, and of the Principal Legal (law of Love). At the same time, he believes that ethics is the basic principle of effective leadership. $\mathrm{He}$ continued that the ethics of the characters are the foundation for the entire building effective life on it, including the leadership. The cornerstone of character integrity build trust as the foundation of life and effective leadership-it can't be replaced, changed, or moved into place because if it is so all the buildings on top of it will collapse.[8] As has been alluded to 
Maxwell about the start of the cessation of the foundation of the integrity of this, Covey also saw that a lot of people misunderstood and replace the foundation of a steady this with the ethics of personality that is oriented on the coating performance outside, the techniques of the nature of the self, the tricks of the psychological, and so on, which is the formation of the image of the outside of the course. Covey asserts that the foundation is thus very fragile and will not survive. While the foundation is steady in this leadership, as called Covey must be integrity which is the statement of the (character) out (embodiment behavior).

Observing this study, then it is reasserted the importance of the role of Law Foundation Which is Steady in a row as well as embodies true leadership, as one of the most important rules that are undeniable in true leadership, and that is irreplaceable. This then also stimulates the author to discuss the review of the implementation of the law foundation of steady this for true leadership.

\section{RESEARCH METHOD}

This research is a qualitative study library (library research) that use books and literature-the literature of other as the object of the main (Hadi, 1995: 3). The type of research used is qualitative research that generates information in the form of notes and descriptive data that are contained in the text under study (Mantras, 2008: 30). With qualitative research, need to be performed descriptive analysis. Methods descriptive analysis provides an overview and description that is clear, objective, systematic, analytical, and critical about the law of leadership that is steady.

A qualitative approach is based on the initial steps taken to gather the data needed, then do the classification and description.

\section{RESULTS AND DISCUSSION}

\section{The legal foundation of a steady}

In his belief, Jhon Maxwell says that from among the 21 laws of leadership in his book, the law foundation of steady is the most important law of all.[9] This is understandable, because this law is the foundation, the main foundation that sustains the whole building leadership at the top, so if the foundation is steady is destroyed, then Destroy it leadership of it.

To refer to the theories about the Legal Foundation of A Steady, that the trust itself is built with involve several factors/qualification, such as Ability, Connection, and Character. However, in the context of the foundation of leadership that vamp this, the character of a leader is a key factor, the key factor and the most 
significant and cannot be compromised in the effort to build trust.

Maxwell argued that the error/failure in terms of the ability and the connection is inexcusable, especially in the context of good character; however, mistakes and failures once in the character damage the foundation of leadership. It made the leadership collapse - no matter how the breadth of connection and talented the person is, it causes very severe damage, it is often difficult to be excused or tolerated by other people/followers, and if it can be repaired it will require a very long time and at great prices.

\section{Coverage Area Legal Foundation In The}

\section{Leadership}

As already explained in the previous section concerning the law foundation of this, that the foundation of a steady in true leadership it is the belief. That trust that allows leadership, and allows the dynamics of leadership that is true it is running and functioning properly.

That belief became the foundation/base that sustains the existence of the leadership, so without good faith as the foundation of a good, then the building of leadership on it will certainly collapse.

The trust itself is a form of credibility and at the same time, a form of appreciation/commitment manifested itself from the other party on the personal and the existence of a leader. As a result, or logical consequences, then trust it even though come by itself naturally, but it was not without foundation or reason. Trust does not come suddenly, or incidentally, was not enforceable. In the study of Maxwell, trust involves the factors of the reasons include: competence, connection, and character.[10]

However, while the issue of competence and connection can be negotiable, and failure in that particular level can be understood, is not the case with the characters. In leadership, a character is dead and can not be negotiable, irreplaceable. So the character or integrity is a decisive factor most important for the creation of trust. Some expert leadership does not always agree with other elements that build and childbirth trust, nevertheless, they always agreed on the elements or factors of the main and most important form of trust, that is the character/ credibility/ integrity and follow other factors.[11] It can be concluded concerning the law foundation of this, that trust is a foundation in the leadership of the true especially the birth of the character, based on and based on the character, credibility, and integrity of a leader. For the same purpose, some authors use the term "credibility" or "integrity". Although the three terms are not completely the same, however, which meant 
concerning the trust it generates is generally the same, namely concerning the qualification of the personal leaders. Citing thinking Stephen R. Covey, coverage of the region is included in the qualification of these characters include integrity, humility, fidelity, self-control, courage, justice, chastity, patience, industry, simplicity, modesty, and Laws (the law of Love: to God and fellow human beings).[12] Meanwhile, Jack W. Hayford says that character and integrity are not the other refers to all the characters spiritual-Christian in a leader.[13]

It can be concluded here that the character of a leader which became the basis for the construction of confidence it is a qualification of the leader of the declared characteristics and moral values, ethics, spiritual, mental supreme; and at the same time integrated and actualized with either in the statement of life: the behavior, attitudes, lifestyle, modeling, and practice leadership.

The reality of life, which thus is a form of integrity. The integrity that is as good as it automatically builds the credibility of strong personal leaders. And on the next turn, it gives birth to a strong belief in the leader, which underlies his leadership over the others.

So, the character, credibility, integrity, and then trust becomes an essential foundation in the leadership of it especially do not speak of material issues of leadership, approach, technique, theory, strategy, planning, or method; not what leaders do, but mainly talking about the "who and how personal the leader".[14] This is about the nature and character of the basis of the personal life of the leader which became the basis of how leadership is constructed and operated, the things which significantly influence the success or failure of his leadership. As revealed by Wayford, Just to have a spiritual character, guaranteed there are fruits of true, a lasting influence in leadership. There is no "the way good job" or "the number of orders and regulations which can produce spiritual leaders spiritual true". Character humane we feel easier to use the time to "plucks a variety of system" rather than prioritize introspection honest to God [which is very important in the formation of character], and the readiness of the continuous to hold the transformation.[15]

With this regard, George Barna argued that without effective leadership, godly, and honor Christ will bring up at the point a sad reality. He added that a Christian leader should be someone with a character like Christ. Because the main function of the leader is to enable people to know, love, and serve God with all my heart, mind, soul, and strength, it can not, the leader himself must, first of all, have a 
personal character that reflects the character of Christ.[16] This is the region that became the basis, the foundation for the construction of true leadership is strong.

In other words, it can be affirmed that the law is the cornerstone of a steady paying attention in the territory of the private life of a leader who leads, which includes all the aspects that build credibility and integrity. Jacob Tomatala reveal that competence in the region character is a factor of the determinant, permanent, [17] as the region remains builder confidence, which has always been the cornerstone of steady leadership. As the region remains within the framework of this foundation, he is irreplaceable, but rather must be constructed starting here. Therefore the region of the cornerstone of the determinant of a permanent and don't replaceable, Tomatala added that there is only one possibility for him, which continues to grow in him through their interaction against/with a variety of other factors.

\section{The Impact Of Correlative Belief On The Dynamics Of Effective Leadership}

In its most basic, the dynamics of effective leadership is built on the foundation of a relationship of mutual trust between leaders and the people he leads, in particular the beliefs of the people which led to the leader. The absence of trust in a leader or a low level of trust in the leader is directly related to the dynamics of leadership, leadership effectiveness, and will further have an impact on the inhibition of a lot of things on the dynamics of a journey of leadership.

Maxwell pointed out the results of the survey of Carnegie-Mellon, who found the presence of a third subordinate who does not trust their superiors, especially because of the problem of credibility, which is very influential on the dynamics of the organization.[18] Cavett Roberts said, as quoted by Maxwell: "If my boys trust me, I will get their acts."

The phrase Robert stated that confidence that leads to the occurrence of the dynamics of leadership that is effective in the implementation of its implementation through subordinates or followers, in terms of obeying and carrying out the decisions/policies/rules/vision, responsibility, dedication/loyalty, in the completion of the task, in the revelation of the contribution, in the involvement maximum, and in a relationship-a relationship that is positive and effective because there is no padding-padding that become an obstacle.

It means obstacles and interference in the trust at the same time have an impact and are directly related to the barriers in the dynamics of an effective course of 
leadership. Having faith means to have and get followers/people-led, at the same time get their hearts together to walk in the vision of the leader, get their commitment, and their responsibility to work together to be a part in the dynamics and the course of its leadership. In a relationship that is bad and lacks confidence, a lot of good things though will be filled with suspicion and lose the dynamics of the effective.

\section{The Impact Of Correlative Belief In The Power Of The And Authority In Leadership}

A true leader, he moved the organization and its people, mobilized, and influence others to follow him and his vision not because the post suggests, it's not the position he had. Even the authority possessed as an integral part of the office and his position does not necessarily establish the authority and power of the ideal in the lead.

Therefore, if only because of those things, then the leadership will be easy to be authoritarian, bullying, and gave birth to patterns of leadership that are not healthy, and undermine leadership, although it seemed to work at the beginning-initially. So a leader has the authority full authority, he needs more than just a name, title, and position is attached to the door of his office.[19] Power and authority in the authority of the effective, i.e. the authority in the authority that can influence, move, that make other people voluntarily follow, declare the commitment, take part, support, stating contributions, and so on, was born from a sincere belief and strong to the integrity and credibility of the leader.

No doubt that the authority in the authority of the power of effective leadership has a direct impact quite knowledgeable on the process and even the success of leadership. Such a situation can only be achieved if there is high trust, things which can not be achieved only with discipline, a firm command, a system of strict supervision, or authority of the organization high/large. Everything that factors a very important role in achieving the ideal situation above, however, the trust underlying all of it, and allowing other factors to play a role effectively.

\section{CONCLUSION}

Presumably not excessive when Maxwell says that the destruction of trust and values in it to make the leadership of someone over. The above descriptions show how trust plays a very crucial and irreplaceable in supporting the leadership, even in enabling leadership that exist and running. Then it can be ascertained, if the 
trust was not there, the leadership will crumble.

The trust that is built and rooted in character, credibility, and integrity is the main determining factor of a permanent nature for true leadership. And through the impacts of the correlative as the discussion above, describe extensively and clearly in terms of the fundamental and the main of which is covered by a foundation of good faith in the leadership, make dynamic leadership, effective, authoritative, and expand the value-the value of the great. And it proves once again that without trust is not possible the achievement of that so it happened.

\section{REFERENCES}

[1]. John C. Maxwell, The 21 Irrefutable Laws of Leadership (21 Laws of Leadership True: Apply the Law of-This Law Then People Will Become Your Followers, Batam Center: Interaksara, 2001, pg. 121; John C. Maxwell, 21 Minutes Most Meaningful In Day-to-Day a True Leader, Batam Center: Interaksara, 2002, pg. 109.

[2]. William A. Cohen, the Art of Leadership, Jakarta: Mitra Disjoint, 1993, pp.. 42; John C. Maxwell,

The 21 Irrefutable Laws of Leadership (21 Laws of Leadership True: Apply the Law of-This Law Then People Will Become Your Followers, Loc.Cit.

[3] John C. Maxwell,
The 21 Irrefutable Laws of Leadership (21 Laws of Leadership True: Apply the Law of-This Law Then People Will Become Your Followers, Loc.Cit.

[4]. John C. Maxwell, John C. Maxwell, Developing Leadership In Yourself, Jakarta: Binarupa Aksara, 1995, p.37, 38; John C. Maxwell, The 21 Irrefutable Laws of Leadership (21 Laws of Leadership True: Apply the Law of-This Law Then People Will Become Your Followers, Loc.Cit.

[5]. John C. Maxwell, 21 Minutes Most Meaningful In Day-To-Day A True Leader, Op.Cit. It.

[6]. John C. Maxwell, John C. Maxwell, Expand Leadership In Yourself,Op Cit., [7]. John C. Maxwell, 21 Minutes Most Meaningful In Day-To-Day A True Leader, Op.Cit. It.

[8]. Stephen R. Covey, The 7 Habits Of Highly Effective People, Jakarta: Binarupa Characters, 1999.

[9]. John C. Maxwell, 21 Minutes Most Meaningful In Day-To-Day A True Leader, Op.Cit. It.

[10]. Cohen, William A., The Art Of Leadership, Jakarta: Mitra Utma

[11]. Barna, George, Leaders On Leadership: The View of The Leaders About Leadership, Malang: Gandum Mas

[12]. Covey, Stephen R. The 7 Habits Of Highly Effective People, Jakarta: Binarupa Aksara

[13]. Hayford, Jack W., in the compilation 
Journal Didaskalia

E-ISSN: 2621-8054

P-ISSN: 2622-1667

of George Barna, Leaders On Leadership: the View of the Leaders About Leadership, Malang: gandum Mas

[14]. Maxwell, John C., Develop Leadership In Yourself, Jakarta: Binarupa Aksara

[15]. Maxwell, John C. The 21 Irrefutable Laws of Leadership (21 Laws of Leadership True: Apply the Law of-This Law Then People Will Become Your Followers, Batam Center: Interaksara.

[16]. Maxwell, John C., 21 Minutes Most Meaningful In Day-To-Day A True Leader, Batam Center: Interaksara

[17]. Octavianus, Peter, Management And Leadership, According to the Revelation of God, Malang: Foundation Fellowship to Preach the Gospel of Indonesia and Wheat Mas

[18]. Tomatala, Jacob, Dynamic Leadership, Malang: Gandum Mas 